\section{MODIFIED “TURN UP” PLUS \\ ADVENTITIA INVERSION \\ TECHNIQUE FOR MANAGING \\ PORCELAIN AORTA}

To the Editor:

Management of severely calcified aorta (porcelain aorta) with aortic valve disease remains controversial. Once the aorta has been opened, placement of sutures for closure along the calcified plate is often challenging. Although various techniques have been reported, currently there is no consensus regarding the appropriate management of this condition. Here we report the clinical outcomes of 2 patients treated with our modified "turn up" and adventitia inversion technique for managing porcelain aorta.

Cardiopulmonary bypass was established through the appropriate accessible arterial and venous lines. Transverse aortotomy at the mid ascending aorta was performed with Cooper scissors. Under hypothermic circulatory arrest, the distal and proximal calcified intimal plate was débrided in such a manner that the redundant adventitia could be inverted on both sides for approximately 1 $\mathrm{cm}$. The modified adventitia inversion technique differs from the originally reported technique ${ }^{1}$ in that the surgeon places sutures through only the inverted adventitia and not the calcified intima. Then, the Dacron polyester fabric graft and the native aorta with its intima inverted are anastomosed with the turn up technique, ${ }^{2}$

\footnotetext{
The Editor welcomes submissions for possible publication in the Letters to the Editor section that consist of commentary on an article published in the Journal or other relevant issues. Authors should: - Include no more than 500 words of text, three authors, and five references. - Type with double-spacing - See http://jtcs.ctsnetjournals.org/misc/ifora.shtm for detailed submission instructions. - Submit the letter electronically via jtcvs.editorialmanager.com. Letters commenting on an article published in the JTCVS will be considered if they are received within 6 weeks of the time the article was published. Authors of the article being commented on will be given an opportunity of offer a timely response ( 2 weeks) to the letter. Authors of letters will be notified that the letter has been received. Unpublished letters cannot be returned.
}

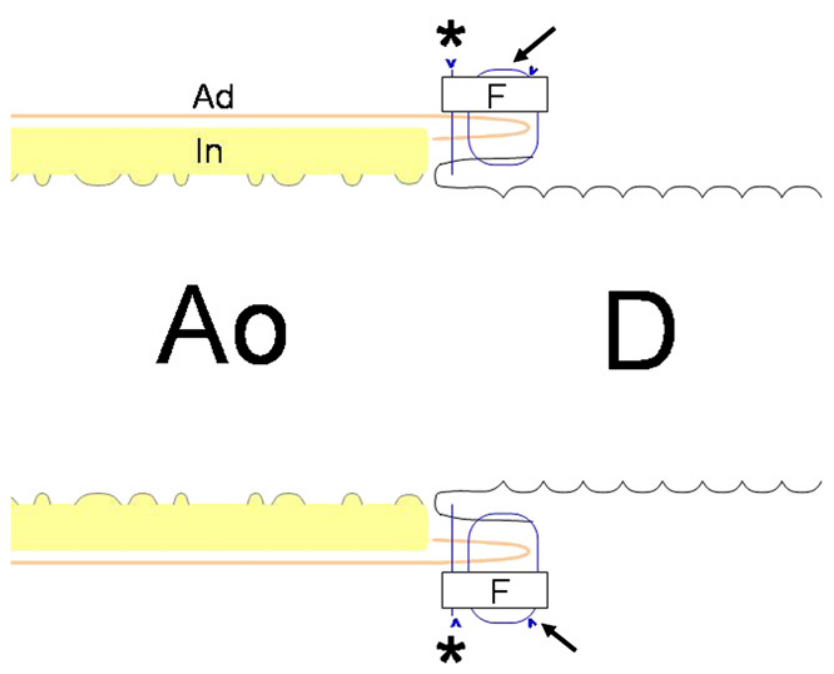

FIGURE 1. Schematic representation of modified turn up and adventitia inversion technique for anastomosis between porcelain aorta and Dacron polyester fabric prosthesis. Note that at edge of porcelain aorta, adventitia is inverted and Dacron polyester fabric prosthesis is everted with 6 to 8 pairs of U stay sutures (asterisk) with felt strip outside, followed by continuous running sutures (arrow) with 4-0 polypropylene. Ad, Adventitia; $F$, felt strip; In, calcified intima; Ao, porcelain aorta; $D$, Dacron polyester fabric prosthesis.

during which first-line 6 to 8 pairs of U stay sutures with felt strip outside are applied to evert the Dacron polyester fabric prosthesis, followed by continuous running sutures over the everted portion with 4-0 polypropylene (Figure 1).

Between February 2006 and October 2010, a total of 2 patients (patient 1, a 74-year-old woman, and patient 2 , a 68-year-old man) with aortic stenosis and porcelain aorta were treated with this technique. Both patients 1 and 2 were dependent on hemodialysis (for 4 and 5 years, respectively). Intraoperatively, replacement of the aortic valve and ascending aorta was performed with our technique without any difficulty. Postoperatively, the contrasted computed tomographic scans of both patients taken at 1 post operative month did not show any abnormal findings, such as development of large hematoma or false aneurysm.

Our technique has several advantages. First, perfect hemostasis is achieved. Both procedures, the turn up method and the adventitia inversion technique, have been performed with proven favorable clinical outcomes for patients with aortic aneurysm or acute aortic dissection. ${ }^{1-3}$ Second, there is minimum need for concern regarding brain complications. Distal anastomosis is performed under hypothermic circulatory arrest without aortic crossclamping, which would otherwise crash the calcified plane and produce numerous sources of cerebral embolic showers. The inverted adventitia partially covers the edge of the calcified intima, which potentially serves as a net for debris. Usually, dissection between the calcified intima and adventitia and inversion of the adventitia are both easy to perform. The 2 layers of the inverted adventitia are sufficiently strong to hold sutures, and they are reinforced by the outside felt strip. The turn up technique achieves hemostasis with a circumferential band of 3- to 5-mm everted prosthesis and native aorta.

In conclusion, the modified turn up and adventitia inversion technique was used to treat 2 patients with porcelain aorta and severe aortic stenosis. The number of patients treated with this technique is obviously limited, 
Future investigation with both a larger patient cohort and a significant follow-up period is therefore necessary to confirm the technique's effectiveness.

Takeshi Shimamoto, MD

Tatsuhiko Komiya, MD

Genichi Sakaguchi, MD

Department of Cardiovascular

Surgery

Kurashiki Central Hospital Kurashiki, Japan

\section{References}

1. Floten HS, Ravichandran PS, Furnary AP, Gately HL, Starr A. Adventitial inversion technique in repair of aortic dissection. Ann Thorac Surg. 1995;59:771-2.

2. Tamura N, Komiya T, Sakaguchi G, Kobayashi T. 'Turn-up' anastomotic technique for acute aortic dissection. Eur J Cardiothorac Surg. 2007;31:548-9.

3. Shimamoto T, Komiya T. Advantage of continuous telescopic inversion technique does not overcome the disadvantage of "turn-up" technique in aortic anastomosis. J Thorac Cardiovasc Surg. In press 2011.

doi:10.1016/j.jtcvs.2011.01.006

\section{NORWOOD PROCEDURE WITH RIGHT VENTRICLE TO \\ PULMONARY ARTERY SHUNT: AN UNDERESTIMATED \\ TECHNICAL SURGICAL \\ VARIABLE \\ To the Editor:}

The recent well-designed randomized study comparing shunt-related outcomes among patients with hypoplastic left heart syndrome at the time of the Norwood operation is a fine addition to the repertoire of evidencebased pediatric cardiac surgery. ${ }^{1}$ There are further potential important technical confounders, however, that may explain the increased incidence of reinterventions after the more recent right ventricle (RV) to pulmonary artery (PA) connection. Why?

We surgeons have our own set of acquired skill sets that can predict good and poor outcomes. We value our experience and that of others, yet we are always inquisitive about which best procedure-patient match predicts lowest morbidity and mortality. We all have our own mental functional equations for outcomes that vary qualitatively and quantitatively. These are based on personal experiences as well as on the collective experiences of others. Variations in transference and application of techniques provide a continued variation in surgical outcome. During this process, room for error generation can prevail. The variety of technical details for reconstructing the RV to PA shunt is one such important example that has both implications and ramifications. These relate to technical redundancy, lack of standardization, and interinstitutional and intrainstitutional practice variations. Another ramification relates to selecting the shunt type and conduit size modification best suited for each particular patient during first-stage palliation.

The modifications include use of different materials (ringed vs plain Gore-Tex, homograft conduit), sizes

TABLE 1. Clinical comparison studies of RV-PA shunts during Norwood procedure

\begin{tabular}{|c|c|c|c|c|c|c|}
\hline Trial & $\begin{array}{c}\text { RV-PA } \\
\text { modification }\end{array}$ & $\begin{array}{c}\text { Modified vs } \\
\text { control } \\
\end{array}$ & $\begin{array}{c}\text { Comparison } \\
\text { in-hospital death } \\
\text { (30-d mortality) }\end{array}$ & $\begin{array}{l}\text { RV-PA conduit } \\
\text { relation to neoaorta }\end{array}$ & $\begin{array}{l}\text { PA confluence } \\
\text { patch (distal } \\
\text { anastomosis) }\end{array}$ & $\begin{array}{c}\text { Direction of } \\
\text { potential } \\
\text { selection bias }\end{array}$ \\
\hline $\begin{array}{c}\text { Hasaniya }^{2} \\
2010\end{array}$ & $\begin{array}{l}\text { Ventricular wall } \\
\text { fixation }\end{array}$ & $\begin{array}{l}13 \text { (ventricular } \\
\quad \text { fixation) vs } 15 \\
\quad \text { (epicardial } \\
\text { fixation) }\end{array}$ & $0 \%$ vs $20 \%$ & Not stated & Yes & $\begin{array}{l}\text { Ventricular wall } \\
\text { fixation prevents } \\
\text { proximal stenosis } \\
(0 \% \text { vs } 20 \%)\end{array}$ \\
\hline $\begin{array}{c}\text { Schreiber }^{3} \\
2006\end{array}$ & $\begin{array}{l}\text { Standard nonringed } \\
\text { Gore-Tex vs } \\
\text { ringed Gore-Tex }\end{array}$ & $28 \mathrm{CC}$ vs $24 \mathrm{RC}$ & $10.7 \%$ vs $13.2 \%$ & Right & Yes & $\begin{array}{l}\text { Ring enforced } \\
\text { prevents stenosis } \\
(23 \text { vs } 45 \%) \text { and } \\
\text { reinterventions ( } 15 \\
\text { vs } 24 \%)\end{array}$ \\
\hline $\begin{array}{c}\text { Reinhartz }^{4} \\
2006\end{array}$ & $\begin{array}{l}\text { Valved homograft } \\
\text { conduit vs } \\
\text { nonhomograft }\end{array}$ & 66 vs 8 & $\begin{array}{l}88.6 \% \text {, insufficient } \\
\text { numbers for } \\
\text { subgroup analysis }\end{array}$ & $\begin{array}{l}\text { Left (per } \\
\quad \text { article figure) }\end{array}$ & No & $\begin{array}{l}\text { Aortic valve } \\
\text { homografts had } \\
\text { early conduit } \\
\text { interventions and } \\
\text { death (OR, 1.34) } \\
\text { compared to } \\
\text { pulmonary } \\
\text { homografts }\end{array}$ \\
\hline $\begin{array}{l}\text { Barron }^{5} \\
2008^{*}\end{array}$ & $\begin{array}{l}\text { Orientation in } \\
\text { relation to } \\
\text { neoaorta }\end{array}$ & $\begin{array}{l}128 \text { right side } \\
\text { vs } 28 \text { left side }\end{array}$ & $88 \%$ vs $75 \%$ & Right or Left & Yes & $\begin{array}{l}\text { Right sided improved } \\
6 \text { month survival } \\
\text { ( } 75 \text { vs } 64 \% \text { ) } \\
\text { compared to left } \\
\text { sided }\end{array}$ \\
\hline
\end{tabular}

$R V$, Right ventricle; $P A$, pulmonary artery; $C C$, nonring-enforced Gortex; $R C$, ring-enforced Gortex. *Control group not included. 